\title{
Article \\ Valorization of Nutritional Potential and Specialized Metabolites of Basil Cultivars Depending on Cultivation Method
}

\author{
Jana Šic Žlabur ${ }^{1} \mathbb{D}$, Nevena Opačić ${ }^{2} \mathbb{D}$, Ivanka Žutić ${ }^{2}$, Sandra Voća ${ }^{1} \mathbb{D}$, Magdalena Poštek $^{1}$, Sanja Radman $^{2, *}$, \\ Božidar Benko ${ }^{2}$ (D) and Sanja Fabek Uher ${ }^{2}$
}

1 Department of Agricultural Technology, Storage and Transport, Faculty of Agriculture, University of Zagreb, Svetošimunska Cesta 25, 10000 Zagreb, Croatia; jszlabur@agr.hr (J.Š.Ž.); svoca@agr.hr (S.V.); megy222@gmail.com (M.P.)

2 Department of Vegetable Crops, Faculty of Agriculture, University of Zagreb, Svetošimunska Cesta 25, 10000 Zagreb, Croatia; nopacic@agr.hr (N.O.); izutic@agr.hr (I.Ž.); bbenko@agr.hr (B.B.); sfabek@agr.hr (S.F.U.)

* Correspondence: sradman@agr.hr

check for updates

Citation: Žlabur, J.Š.; Opačić, N.; Žutić, I.; Voća, S.; Poštek, M.; Radman, S.; Benko, B.; Uher, S.F. Valorization of Nutritional Potential and Specialized Metabolites of Basil Cultivars Depending on Cultivation Method. Agronomy 2021, 11, 1048. https://doi.org/10.3390/ agronomy11061048

Academic Editor: Carla Gentile

Received: 8 May 2021

Accepted: 21 May 2021

Published: 24 May 2021

Publisher's Note: MDPI stays neutral with regard to jurisdictional claims in published maps and institutional affiliations.

Copyright: (c) 2021 by the authors. Licensee MDPI, Basel, Switzerland. This article is an open access article distributed under the terms and conditions of the Creative Commons Attribution (CC BY) license (https:/ / creativecommons.org/licenses/by/ $4.0 /)$.

\begin{abstract}
In addition to its distinct aroma and flavor, because of which it is often used in various foods and dishes, basil has recently become increasingly popular because of its rich and beneficial nutritional composition. The presence of several varieties and cultivars makes it a species rich in many specific phytochemicals, which is why it is increasingly used in phytotherapy. The aim of this study was to analyze and valorize the nutrient composition and morphological characteristics of three different basil cultivars ('Genovese', 'Dark Opal', 'Minimum') under two growing methods, conventional in open field and floating hydropon. The results of morphological and chemical characteristics showed a significant influence of cultivar in both growing methods. The cultivar 'Genovese' obtained the highest yield in floating hydropon $\left(4.02 \mathrm{~kg} / \mathrm{m}^{2}\right)$, followed by cultivars 'Minimum' and 'Dark Opal' (2.03 and $1.83 \mathrm{~kg} / \mathrm{m}^{2}$, respectively), which were $31 \%, 97 \%$, and 16\% higher compared to soil cultivation. Based on the analyzed physicochemical parameters, the highest values of dry matter, total acids, vitamin C, total phenols, and antioxidant capacity were generally determined in all analyzes basil cultivars grown in the open field compared to those grown in floating. Significantly higher values of the analyzed pigment compounds were found for all hydroponically grown basil cultivars.
\end{abstract}

Keywords: floating system; morphologically characteristics; total phenolics; pigment compounds; Ocimum basilicum

\section{Introduction}

The genus Ocimum is characterized by great variability in both morphological characteristics and chemical composition, as evidenced by numerous cultivars and chemotypes with different growth, yield, and raw material quality characteristics [1-3]. Among the number of species in genus, Ocimum basilicum L. (basil) has been the most often used, primary as a culinary herb, then in the cosmetic industry and as an ornamental plant [1]. According to Makri and Kintzios [4], O. basilicum could be generally classified into several groups: tall slender type ('Sweet basil'), robust type with large leaves ('Italian basil'), dwarf type with small leaves ('Bush basil'), purple-colored types (including var. purpurascens), and lemon-flavored basil (including $\times$ citriodorum).

Basil contains a large amount of essential oil and antioxidant polyphenolic compounds with anticancer, antibacterial, antiviral, antifungal, and anti-inflammatory properties [5]. It is a rich source of vitamins $(\mathrm{E}, \mathrm{A}, \mathrm{B} 6, \mathrm{C}, \mathrm{K})$, minerals $(\mathrm{Ca}, \mathrm{K}, \mathrm{P}, \mathrm{Mg}$, Fe), pigments, and other specialized metabolites (SM), mainly essential oil components (terpenes, phenylpropanoids, 
alcohols, and aldehydes) [6] and polyphenols, mainly phenolic acids and flavonol glycosides. Basil leaves contain one of the most strongly identified antioxidants, rosmarinic acid, which, along with other identified polyphenols, gives basil a strong antioxidant effect $[7,8]$. Such a rich and significant nutritional composition of basil is extremely important, especially at a time when we are aware of how nutraceuticals, or phytochemicals as a significant food ingredient, contribute significantly to the body's fight against many pathogenic bacteria, viruses (SARS-Cov-19), and generally to strengthen the immune system [9]. The specific composition of the phytochemicals as well as their content differ considerably, depending on the cultivars, on genetic characteristics, but also strongly on essential abiotic (environmental factors) and biotic factors, agrotechnical measures (cultivation methods, fertilization), and other factors which have the greatest significance for the final content in the plant material [7].

Basil is a native herb in Asia and can be found wild in tropical and sub-tropical regions, and due to its origin, has strict climatic requirements, especially to light and temperature [2], so its cultivation in open field meets numerous problems [10]. Restricting environmental factors in basil cultivation can be controlled by greenhouse cultivation, using modern growing technologies. Further, cultivation under controlled conditions also allows its availability all year round. One of them is floating system, a hydroponic technique carried out under controlled conditions, giving reproducibility by uniformity of growth conditions and a better control of nutrient supply [11]. It is used successfully for the production of leafy vegetables, with a short cultivation period such as lettuce, spinach, rocket, aromatic plants, and herbs. Advantages of this system are lower costs of production, reduced foliar disease infestations, more efficient use of water and nutrients, resulting in rapid growth, earlier harvest, a larger number of production cycles, and higher yield all year round [12-14]. Concentrations of SM, as the most important compounds in basil, are influenced by many factors, including soil, irrigation, and climatic conditions [11,13]. Indeed, it is important to point out that the activation of specific metabolic SM pathways in plants requires a significant amount of energy, nutrients, and biotic and abiotic signals. Thus, in hydroponic cultivation, both biotic and abiotic factors are well controlled, and the most important one for optimizing SM synthesis and production is mineral nutrition of plants. Thus, a major challenge in hydroponics is supra-optimal effects of nutrient supply on both plant growth and SM accumulation [15].

Therefore, the aim of this study was to analyze and valorize the basic morphological characteristics and nutritional composition of three basil cultivars ('Genovese', 'Minimum', 'Dark Opal') belonging to different varieties of O. basilicum (var. basilicum, var. minimum, var. purpurascens) using two cultivation systems (hydroponic floating system and conventional cultivation in soil in open field).

\section{Materials and Methods}

\subsection{Plant Material}

The experiment was set up at the University of Zagreb Faculty of Agriculture at Department of Vegetable Crops. Three basil cultivars (cv.) belonging to the three different types of $O$. basilicum (cv. 'Genovese' of sweet basil type O. basilicum var. basilicum; cv. 'Minimum' of Bush basil O. basilicum var. minimum; cv. 'Dark Opal' of purple-colored type O. basilicum var. purpurascens, (Hortus sementi, Italy) were cultivated by two growing methods: in a floating hydroponic system in the greenhouse and in the soil in the open field.

\subsection{Cultivation in Floating System}

Cultivation in floating hydroponics was carried out in a greenhouse $\left(45^{\circ} 49^{\prime} 33.2^{\prime \prime} \mathrm{N}\right.$ $16^{\circ} 01^{\prime} 44.6^{\prime \prime} \mathrm{E}$ ) under controlled conditions. Temperature and relative air humidity were adjusted to the requirements of the species, with average values for temperature of $22.5^{\circ} \mathrm{C}$ and relative humidity of $70 \%$. Sowing in polystyrene boards $\left(0.576 \mathrm{~m}^{2}\right)$ filled with inert substrate perlite (Europerl d.o.o., Samobor, Croatia) was done on 20 April. The experiment was conducted according to the randomized complete block design with 3 replications 
where each repetition of the cultivar was represented by one polystyrene board. The complete graphical scheme of floating hydroponics cultivation is represented in Figure 1. Boards without inscription represent the boundary boards that served to cover the entire surface of the pool (protection from insects, excessive availability of oxygen and light, conditions conducive to the formation of undesirable algae). Per one slit of the board, 10 seeds were sown and required seed amounts depended on the seed size of cultivar ('Genovese' $2.86 \mathrm{~g} / \mathrm{m}^{2}$; 'Dark Opal' $2.51 \mathrm{~g} / \mathrm{m}^{2}$; 'Minimum' $0.66 \mathrm{~g} / \mathrm{m}^{2}$ ). Abiotic factors $[\mathrm{pH}$ value, electric conductivity (EC), and oxygen level] of nutrient solution were measured every five days. Their average values during basil vegetation period amounted $6.82(\mathrm{pH})$, $2.21 \mathrm{dS} / \mathrm{m}$ (EC), and $3.8 \mathrm{mg} / \mathrm{L}$ (oxygen level), as recommended for leafy vegetables according to Osvald and Kogoj-Osvald, [16].

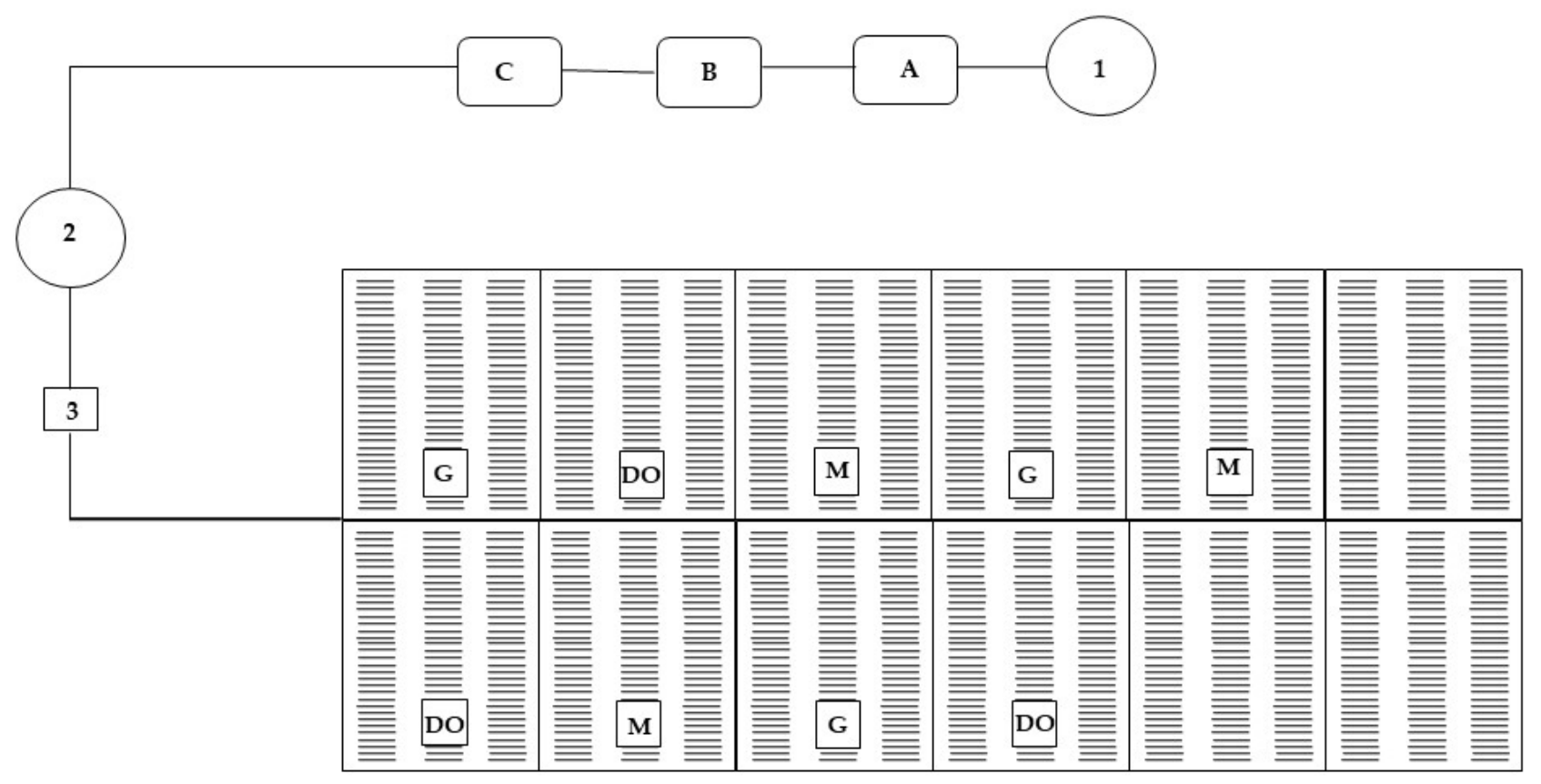

Figure 1. Graphical scheme of floating hydroponics cultivation of three different sweet basil cultivars ('Genovese', 'Minimum', 'Dark Opal'). 1-water tank; A, B, C—tanks for concentrated nutrient solutions and injectors; 2-tank for standard nutrient solution applied in floating hydroponics; 3-pump. G-'Genovese'; M-'Minimum'; DO-'Dark Opal'.

Nutrient solution was adapted to basil cultivation according to Tesi [17], and was composed of $7.76 \mathrm{mmol} / \mathrm{L} \mathrm{KNO}_{3}, 0.35 \mathrm{mmol} / \mathrm{L} \mathrm{NH}_{4} \mathrm{NO}_{3}, 0.90 \mathrm{mmol} / \mathrm{L} \mathrm{Ca}\left(\mathrm{NO}_{3}\right)_{2}$, and $40 \mu \mathrm{mol} / \mathrm{L} \mathrm{FeSO}_{4}$ contained in tank A. In tank $\mathrm{B}$, there were $1.00 \mathrm{mmol} / \mathrm{L} \mathrm{MgSO}_{4}$, $2.00 \mathrm{mmol} \mathrm{L}-1 \mathrm{KH}_{2} \mathrm{PO}_{4}, 0.12 \mathrm{mmol} / \mathrm{L} \mathrm{K}_{2} \mathrm{SO}_{4}, 30 \mu \mathrm{mol} / \mathrm{L} \mathrm{H}_{3} \mathrm{BO}_{4}, 5 \mu \mathrm{mol} / \mathrm{L} \mathrm{MnSO}_{4}$, $4 \mu \mathrm{mol} / \mathrm{L} \mathrm{ZnSO}_{4}, 0.50 \mu \mathrm{mol} / \mathrm{L} \mathrm{Na}_{2} \mathrm{MoO}_{4}$, and $0.75 \mu \mathrm{mol} / \mathrm{L} \mathrm{CuSO}_{4}$. In tank $\mathrm{C}$, there was $0.03 \mathrm{mmol} / \mathrm{L} \mathrm{HNO}_{3}$. Harvest of basil plants was performed before flowering stage on 17 June.

\subsection{Cultivation in Soil in the Open Field}

Transplant production began on March 22 in a heated greenhouse, in polystyrene containers with 84 pots filled with commercial substrate (Klasman Potgrond $\mathrm{H}$ ). Five seeds per pot were sown and after one month, the transplants were pricked into containers with a larger pot volume, with 40 pots.

Initial fertilization on the experimental plots in the field was done just before sowing at rates of $40 \mathrm{~kg} / \mathrm{ha} \mathrm{N}$ and $20 \mathrm{~kg} / \mathrm{ha} \mathrm{K}$. Phosphorus was added at a rate of $40 \mathrm{~kg} / \mathrm{ha}$ last autumn [18]. Planting in the open field $\left(45^{\circ} 49^{\prime} 32.6^{\prime \prime} \mathrm{N} 16^{\circ} 01^{\prime} 43.9^{\prime \prime} \mathrm{E}\right)$ at $50 \mathrm{~cm} \times 30 \mathrm{~cm}$ spacing ( 6.6 planting place $/ \mathrm{m}^{2}$ ) was done in the period after the last spring frost (17 May). The trial was conducted according to the randomized block design in three replications 
(Figure 2). Irrigation and other usual measures of crop maintenance were carried out as needed. Harvest was conducted at the beginning of the flowering stage, on $15 \mathrm{July}$.

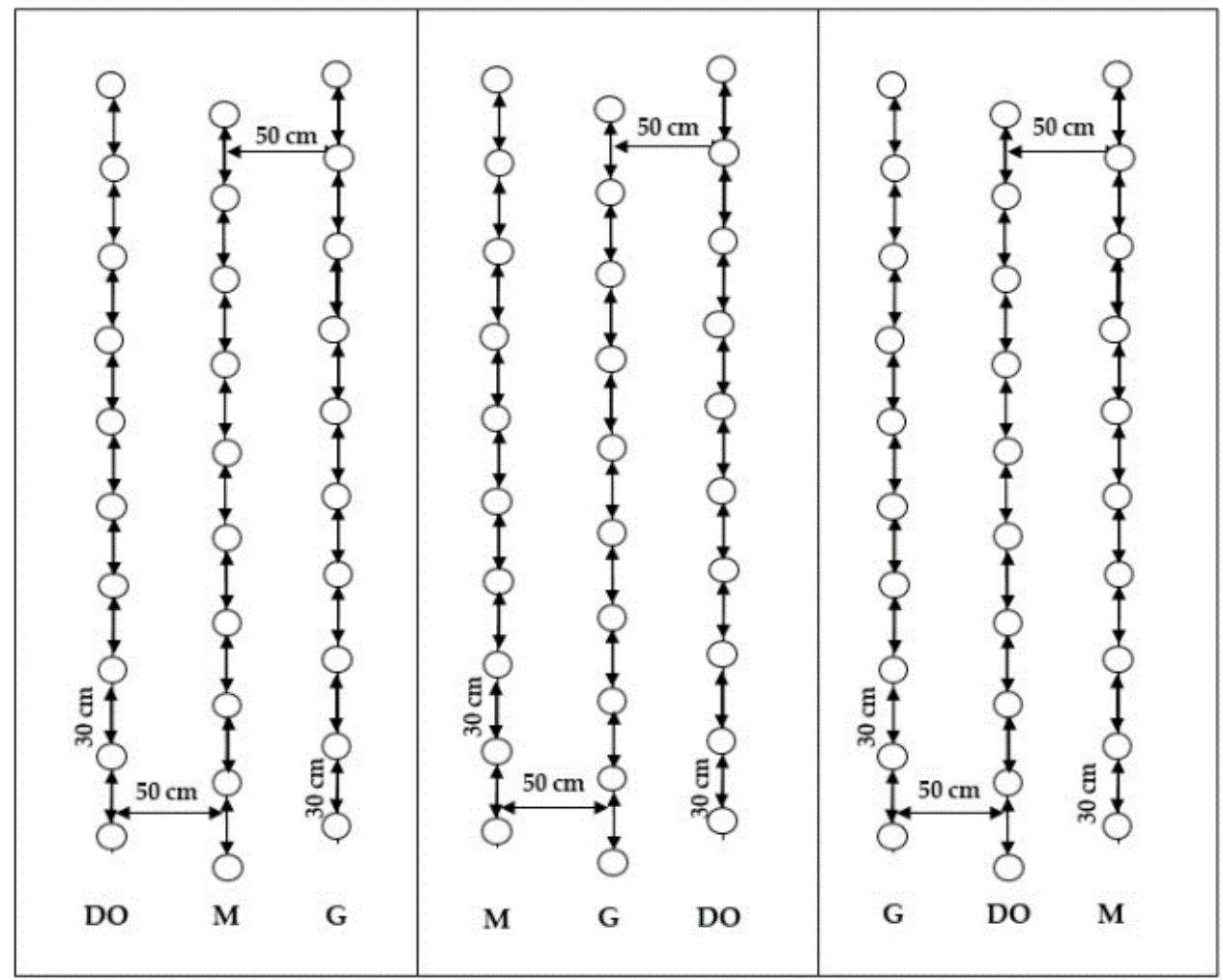

Figure 2. Graphical scheme of open field cultivation of different sweet basil cultivars ('Genovese', 'Minimum', 'Dark Opal'). G-'Genovese'; M-'Minimum'; DO-'Dark Opal'. The arrows indicate the density of the planting for each cultivar (row spacing and plants in each row).

On the day of planting, the mean daily air temperature at the experimental site was $11.5^{\circ} \mathrm{C}$, while the maximum temperature increased to $17.9^{\circ} \mathrm{C}$. In the week following planting, temperatures rose by 8 degrees and rain fell $(12.7 \mathrm{~mm})$, favoring rooting and growth of the planted transplants (data not shown) [19].

\subsection{Morphological Analysis}

On 10 plants per repetition of each cultivar, next, morphological parameters were analyzed: plant mass (g), number of leaves per plant, length and width of the largest leaf per plant $(\mathrm{cm})$, plant height $(\mathrm{cm})$, and total yield $\left(\mathrm{kg} / \mathrm{m}^{2}\right)$. After harvests, representative samples were prepared by separating leaves and young apical parts from stems and transported to the Department of Agricultural Technology, Storage, and Transport at the University of Zagreb at the Faculty of Agriculture for further chemicals analysis.

\subsection{Determination of Physico-Chemical Parameters and Specialized Metabolites Content}

The analysis of basic chemical composition of selected basil cultivars included determination of dry matter content (\%) by drying till constant mass, total acid content (\%) by potentiometric titration and $\mathrm{pH}$-value by digital $\mathrm{pH}$-meter (Mettler Toledo, SevenMulty, Switzerland) carried out by standard methods [20].

From bioactive compounds, vitamin $C$ content was determined by titration with 2,6dichlorindophenol (DKF) according to [21]. For each cultivar, $10 \mathrm{~g} \pm 0.01$ of fresh basil leaves were homogenized with $100 \mathrm{~mL}$ of $2 \%(v / v)$ oxalic acid. After homogenization, the solution was filtered through Whatman filter paper, the filtrate was obtained in a volume of $10 \mathrm{~mL}$ and titrated with freshly prepared 2,6-dichloroindophenol until pink 
coloration appeared. The final vitamin $C$ content was calculated according to Equation (1) and expressed as $\mathrm{mg} / 100 \mathrm{~g}$ fresh weight.

$$
\operatorname{Vitamin} C=\frac{V(D K F) \times F}{D} \times 100
$$

where $V(D K F)$ —volume of DKF (mL); F-factor of DKF; D—sample mass used for titration.

Total phenolics (TPC) including flavonoids (TFC) and non-flavonoids (TNFC) content were determined spectrophotometrically (Shimadzu, UV 1650 PC) using a method based on a color reaction that phenolics develop with Folin-Ciocalteu reagent, measured at $750 \mathrm{~nm}$ according to Ough and Amerine [22]. For the purpose of isolation of polyphenolic compounds from plant leaves, ethanol solution $(80 \%, v / v)$ and reflux were combined. Fresh plant material of $10 \mathrm{~g} \pm 0.01$ was weighed into an Erlenmeyer flask and the first $40 \mathrm{~mL}$ of $80 \% \mathrm{EtOH}(v / v)$ was added. The prepared sample was heated to boiling point and additionally refluxed for $10 \mathrm{~min}$. After $10 \mathrm{~min}$, the sample was filtered through Whatman filter paper into a volumetric flask of $100 \mathrm{~mL}$. After filtration, the rest of the sample was transferred to the Erlenmeyer flask and another $50 \mathrm{~mL}$ of $80 \% \mathrm{EtOH}(v / v)$ was added while the procedure was repeated with reflux for $10 \mathrm{~min}$. The sample was filtered in the same volumetric flask, the filtrates were combined and the flask was made up to the mark with $80 \% \mathrm{EtOH}(v / v)$. The extract thus prepared was used for the reaction with reagent Folin-Ciocalteu. To a volumetric flask of $50 \mathrm{~mL}, 0.5 \mathrm{~mL}$ of the ethanolic extract and the following chemicals were added: $30 \mathrm{~mL}$ of distilled water $\left(\mathrm{dH}_{2} \mathrm{O}\right), 2.5 \mathrm{~mL}$ of the prepared reagent Folin-Ciocalteu $\left(1: 2\right.$ with $\left.\mathrm{dH}_{2} \mathrm{O}\right)$, and $7.5 \mathrm{~mL}$ of saturated sodium carbonate solution $\left(\mathrm{Na}_{2} \mathrm{CO}_{3}\right)$; the flask was made up to the mark with $\mathrm{dH}_{2} \mathrm{O}$ and the prepared sample was allowed to stand at room temperature for $2 \mathrm{~h}$ with intermittent shaking. The same ethanolic extracts prepared for TPC determination were used for TNFC content determination, while TNFC separation was performed according to the following procedure: $10 \mathrm{~mL}$ of the ethanolic extract was added to the $25 \mathrm{~mL}$ capacity volumetric flask, then $5 \mathrm{~mL}$ of $\mathrm{HCl}(1: 4, v / v)$ and $5 \mathrm{~mL}$ of formaldehyde were added. The prepared samples were bubbled with nitrogen $\left(\mathrm{N}_{2}\right)$ and left for $24 \mathrm{~h}$ at room temperature in a dark place. After $24 \mathrm{~h}$, the same Folin-Ciocalteu reaction was performed as for TPC. The absorbance of blue color in both TPC and TNFC reactions was measured spectrophotometrically at $750 \mathrm{~nm}$ using distilled water as a blank. Gallic acid and catechol were used as external standards and the concentration of TPC and TNFC content was expressed as mg GAE/100 g fresh weight. TFC content was mathematically expressed as the difference between total phenols and non-flavonoids.

Analyzes of pigment compounds included determination of total anthocyanins content by the bisulfite bleaching method described by Ough and Amerine [22]. Total anthocyanins were analyzed spectrophotometrically at $520 \mathrm{~nm}$ for $\mathrm{cv}$. 'Dark Opal' according to following procedure: $2 \mathrm{~g} \pm 0.01$ fresh basil leaves were weighed into $50 \mathrm{~mL}$ cuvette volume, $2 \mathrm{~mL}$ of $0.1 \% \mathrm{HCl}$ (diluted with $96 \% \mathrm{EtOH}$ ) and $40 \mathrm{~mL}$ of $2 \% \mathrm{HCl}(v / v)$ were added. The prepared samples were centrifuged at $4500 \mathrm{rpm}$ for $10 \mathrm{~min}$. After centrifugation, $10 \mathrm{~mL}$ of the supernatant was separated into one test tube and $10 \mathrm{~mL}$ into another test tube. To the first test tube, $4 \mathrm{~mL}$ of $\mathrm{dH}_{2} \mathrm{O}$ was added (blank), and to the second, $4 \mathrm{~mL}$ of a freshly prepared solution of $15 \%$ sodium bisulfite $\left(\mathrm{NaHSO}_{3}, v / v\right)$. The samples thus prepared were allowed to stand in the test tubes for $15 \mathrm{~min}$, while thereafter the absorbances (A1 for the blank and A2 for the reaction with bisulfite) were measured spectrophotometrically at $520 \mathrm{~nm}$ with $2 \% \mathrm{HCl}(v / v)$ as the blank. The final anthocyanin content (TAC) was calculated from the difference in absorbance (A1-A2) multiplied by the molar mass of the most abundant anthocyanin and expressed as $\mathrm{mg} / \mathrm{kg}$.

Total chlorophylls and carotenoids were analyzed according to method described by Holm [23] and Wettstein [24]. To isolate chlorophyll and carotenoid pigments from basil leaves, $0.2 \mathrm{~g} \pm 0.01$ fresh plant material was weighed and a total volume of $15 \mathrm{~mL}$ of acetone (p.a.) was added three times. After each addition of acetone, the samples were homogenized using a laboratory homogenizer (IKA, UltraTurax T-18, Staufencity, 
Germany). The final solution was filtered and transferred to a volumetric flask of $25 \mathrm{~mL}$. The absorbance was measured spectrophotometrically (Shimadzu UV 1650 PC, Japan) at 662,644 , and $440 \mathrm{~nm}$ using acetone as a blank. To obtain the results for pigment content based on the claimed absorbance, the equations of Holm -Wettstein were used (2). The final results for the pigment contents were expressed in $\mathrm{mg} / \mathrm{g}$.

chlorophyll a $=9.784 \times$ A_662-0.990 $\times$ A_(644) $[\mathrm{mg} / \mathrm{L}]$

chlorophyll b=21.426 $\times$ A_644-4.65 $\times$ A_662 [mg/L]

total chlorophyll $=5.134 \times$ A_662 $+20.436 \times$ A_644 $[\mathrm{mg} / \mathrm{L}]$

total carotenoids $=4.695 \times$ A_440-0.268 $\times$ total chlorophyll $[\mathrm{mg} / \mathrm{L}]$

Antioxidant capacity by ABTS assay was performed according to Miller et al. [25]. ABTS, 2,20-azinobis (3-ethylbenzothiazoline-6-sulfonic acid), and potassium persulfate were obtained from Sigma-Aldrich. As antioxidant standard Trolox (6-hydroxy-2,5,7,8tetramethylchroman-2-carboxylic acid; Sigma-Aldrich, St. Louis, MO, USA) was used. As a stock standard, Trolox $(2.5 \mathrm{mM})$ was prepared in ethanol $(80 \%)$. To prepare ABTS radical solution (ABTS 1), the $5 \mathrm{~mL}$ of ABTS solution $(7 \mathrm{mM})$ and $88 \mathrm{~mL}$ of potassium persulfate $(140 \mathrm{mM})$ solution were mixed and allowed to stand in the dark at room temperature for $16 \mathrm{~h}$. On the day of analysis, 1\% ABTS 1 solution (in 96\% ethanol) was prepared. A total of $160 \mu \mathrm{L}$ of extract were directly injected in the cuvette and mixed with $2 \mathrm{~mL} \mathrm{1 \%} \mathrm{ABTS} \mathrm{1,}$ while absorbance at $734 \mathrm{~nm}$ was measured (Shimadzu 1650 PC, Germany). The final results of the antioxidant capacity were calculated based on calibration curve and expressed as $\mu \mathrm{mol} \mathrm{TE} / 1$.

\subsection{Statistical Analysis}

The two-factorial experiment was set up by randomized block design in three replicates. A generalized linear model was used which included the cultivation method (floating and open field), and cultivar ('Genovese', 'Minimum', 'Dark Opal') as categorical predictors. For the analytical procedures, PROC GLM in SAS software package, version 9.3. (2010) [26] was used. The data obtained were analyzed using analysis of variance (ANOVA). Means were compared using t-test (LSD) and were considered significantly different at $p \leq 0.0001$. Different letters are presented in the tables to indicate significant differences between the means within each column. The standard deviation $( \pm \mathrm{SD})$ was also indicated.

\section{Results}

\subsection{Morphological Properties of Basil Cultivars}

The results of morphometric traits (plant mass and height, number of leaves, dimensions of leaves) as basic yield components, depending on growing method, are presented in Table 1. There is a significant influence of cultivar (C), growing method (G), and their interaction $\mathrm{C} \times \mathrm{G}$ on all observed morphological properties of basil cultivars. The exception is the plant mass trait, where the influence of growing method (G) was not statistically justified. The highest plant mass was found for cv. 'Genovese' both in floating (20.7\%) and in soil $(27.7 \%)$. The same trend was observed for leaf length (both in floating and in soil- $8.5 \mathrm{~cm})$ as well as for plant height $(33.7 \mathrm{~cm})$ and leaf width $(6.4 \mathrm{~cm})$, but only in floating conditions. The cultivar 'Minimum' had the largest number of leaves in both growing methods (floating-114.9; soil-118.0), but its dimensions were the smallest compared to the cultivars 'Genovese' and 'Dark Opal'. Regardless of cultivar, the values of certain morphometric traits (plant height and leaf size) were generally higher in the floating system compared to the soil. 
Table 1. Morphometric traits and yield of basil cultivars depending on growing system.

\begin{tabular}{|c|c|c|c|c|c|}
\hline Cultivar & Plant Mass (g) & Plant Height $(\mathrm{cm})$ & Number of Leaves & $\begin{array}{l}\text { Length of Leaves } \\
(\mathrm{cm})\end{array}$ & $\begin{array}{l}\text { Width of Leaves } \\
(\mathrm{cm})\end{array}$ \\
\hline \multicolumn{6}{|c|}{ Floating } \\
\hline 'Minimum' & $13.7^{b c} \pm 1.4$ & $16.9^{c} \pm 1.9$ & $114.9^{a} \pm 20.6$ & $4.0^{\mathrm{b}} \pm 0.1$ & $1.5^{\mathrm{d}} \pm 0.1$ \\
\hline 'Genovese' & $20.7^{\mathrm{ab}} \pm 4.7$ & $33.7^{\mathrm{a}} \pm 4.4$ & $15.1^{\mathrm{c}} \pm 2.7$ & $8.5^{\mathrm{a}} \pm 4.1$ & $6.4^{\mathrm{a}} \pm 0.7$ \\
\hline 'Dark Opal' & $16.1^{\mathrm{bc}} \pm 3.6$ & $23.0^{\mathrm{b}} \pm 1.7$ & $34.9^{b c} \pm 2.7$ & $11.3^{a} \pm 0.9$ & $6.0^{\mathrm{a}} \pm 0.5$ \\
\hline \multicolumn{6}{|c|}{ Open field } \\
\hline 'Minimum' & $9.6^{c} \pm 2.6$ & $15.4^{\mathrm{c}} \pm 1.7$ & $118.0^{\mathrm{a}} \pm 27.7$ & $2.5^{b} \pm 0.2$ & $1.5^{\mathrm{d}} \pm 0.3$ \\
\hline 'Genovese' & $27.7^{\mathrm{a}} \pm 8.1$ & $24.8^{b} \pm 0.9$ & $51.5^{b} \pm 9.7$ & $8.5^{a} \pm 0.8$ & $5.1^{\mathrm{b}} \pm 0.4$ \\
\hline 'Dark Opal' & $16.1^{b c} \pm 3.2$ & $24.5^{b} \pm 1.2$ & $57.5^{b} \pm 4.6$ & $5.2^{b} \pm 0.4$ & $3.4^{c} \pm 0.3$ \\
\hline ANOVA & $p \leq 0.0113$ & $p<0.0001$ & $p \leq 0.0001$ & $p \leq 0.0025$ & $p \leq 0.0001$ \\
\hline LSD & 7.7607 & 4.2007 & 28.868 & 3.2302 & 0.7701 \\
\hline Cultivar (C) & 0.0021 & 0.0001 & 0.0001 & 0.0004 & 0.0001 \\
\hline $\begin{array}{l}\text { Growing method } \\
(\mathrm{G})\end{array}$ & 0.6659 & 0.0211 & 0.0159 & 0.0107 & 0.0001 \\
\hline $\mathrm{C} \times \mathrm{G}$ & 0.1566 & 0.0077 & 0.2161 & 0.0290 & 0.0014 \\
\hline
\end{tabular}

Results are expressed as mean \pm standard deviation. Different letters indicate significant differences between mean values.

The yield of the investigated basil cultivars as a function of growing method is shown in Figure 3. Irrespective of the basil cultivar, 1.4 times higher yield was recorded for the cultivars grown in floating as compared to soil cultivation (floating- $2.62 \mathrm{~kg} / \mathrm{m}^{2}$; open field $-1.89 \mathrm{~kg} / \mathrm{m}^{2}$ ). The highest yields in both growing methods were recorded for the $\mathrm{cv}$. 'Genovese' (floating-4.02 kg/m²; soil-3.06 kg/m²). Despite the lowest yield obtained in soil, the cultivar 'Minimum' should be highlighted here, which yielded $97 \%$ higher in floating system. Unlike, the smallest difference in yield obtained in the comparison of the two growing methods had the variety 'Dark Opal', only 16\% less in the open field.

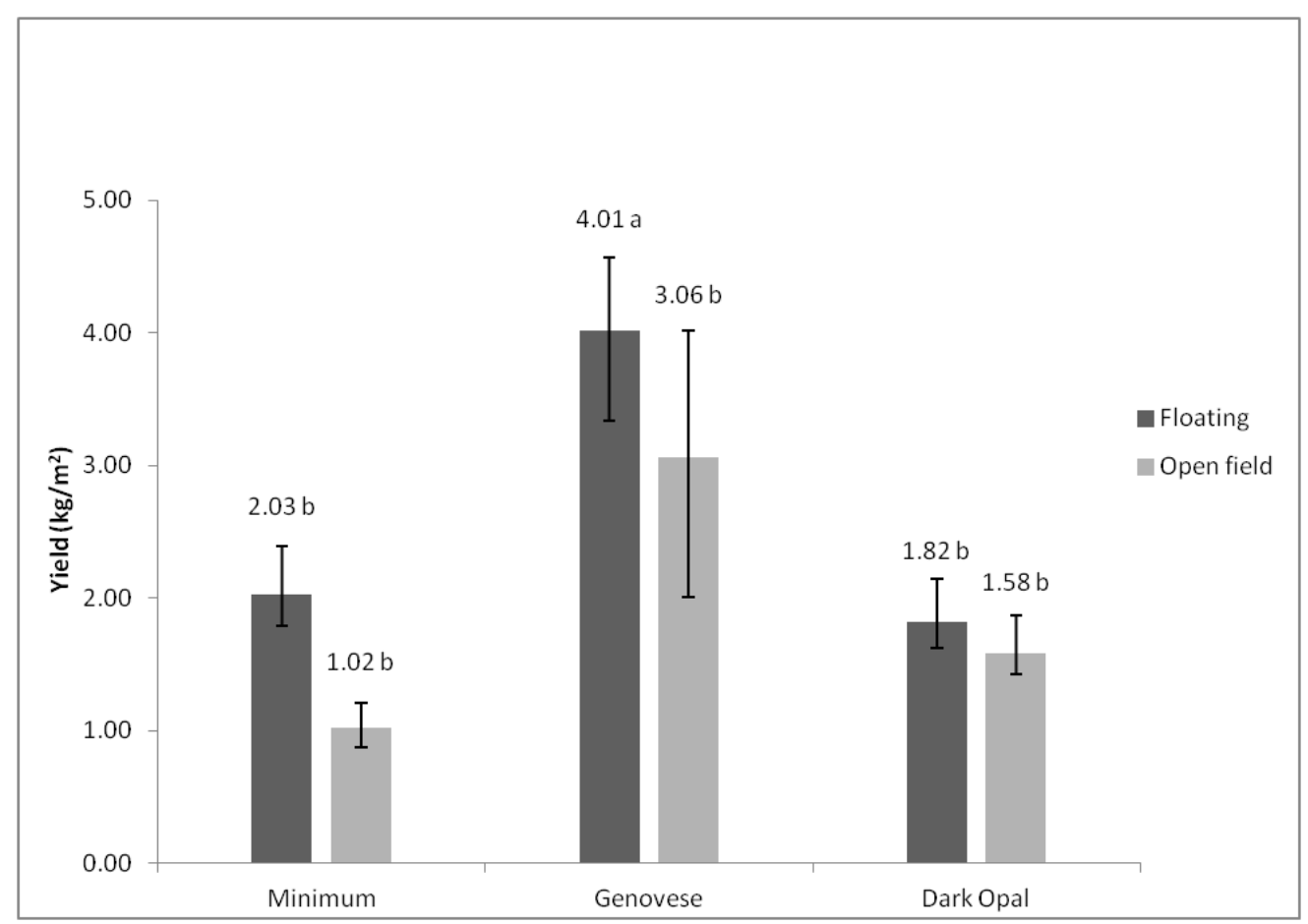

Figure 3. Yield $\left(\mathrm{kg} / \mathrm{m}^{2}\right)$ of three sweet basil cultivars grow in floating hydropon and in open field. Different letters indicate significant differences between mean values at $p \leq 0.0017$. Significance of interaction: Cultivar (C) $p \leq 0<0.0001$; Growing method $(\mathrm{G}) p \leq 0.0168$; Interaction $\mathrm{C} \times \mathrm{G} p \leq 0.4367$. 


\subsection{Physico-Chemical Parameters of Basil Cultivars}

Significantly different $(p \leq 0.0001)$ values of dry matter content (DM), total acid (TA) content, and $\mathrm{pH}$-value were found between all three basil cultivars depending on the studied cultivation method (Table 2). The analysis of the significance of the interactions between the combined variables (Table 2) shows a significant influence of the cultivar $(C)$, the cultivation method $(\mathrm{G})$, and their interaction $\mathrm{C} \times \mathrm{G}$ on all the analyzed physicochemical parameters of the basil cultivars.

Table 2. Physico-chemical composition of basil cultivars depending on cultivation method.

\begin{tabular}{cccc}
\hline Cultivar & DM (\%) & TA (\%) & pH-value \\
\hline \multicolumn{3}{c}{ Floating } \\
\hline 'Minimum' & $10.13^{\mathrm{c}} \pm 0.09$ & $0.063^{\mathrm{c}} \pm 0.01$ & $6.31^{\mathrm{a}} \pm 0.04$ \\
'Genovese' & $8.76^{\mathrm{e}} \pm 0.39$ & $0.050^{\mathrm{c}} \pm 0.01$ & $6.04^{\mathrm{bc}} \pm 0.02$ \\
'Dark Opal' & $9.33^{\mathrm{d}} \pm 0.14$ & $0.053^{\mathrm{c}} \pm 0.004$ & $5.99^{\mathrm{cd}} \pm 0.02$ \\
\hline \multicolumn{4}{c}{ Open field } \\
\hline \multicolumn{5}{c}{$0.103^{\mathrm{b}} \pm 0.006$} & $5.93^{\mathrm{d}} \pm 0.03$ \\
'Minimum' & $19.15^{\mathrm{a}} \pm 0.17$ & $0.057^{\mathrm{c}} \pm 0.02$ & $6.09^{\mathrm{b}} \pm 0.01$ \\
'Genovese' & $11.65^{\mathrm{b}} \pm 0.52$ & $0.353^{\mathrm{a}} \pm 0.006$ & $6.02^{\mathrm{bcd}} \pm 0.08$ \\
\hline Dark Opal' & $11.77^{\mathrm{b}} \pm 0.30$ & $p \leq 0.0001$ & $p \leq 0.0001$ \\
\hline ANOVA & $p \leq 0.0001$ & 0.0185 & 0.1096 \\
\hline LSD & 0.5127 & 0.0001 & 0.0199 \\
\hline Cultivar (C) & 0.0001 & 0.0001 & 0.0053 \\
C $\times$ G & 0.0001 & 0.0001 & 0.0001 \\
\hline
\end{tabular}

DM-dry matter content; TA-total acid content. Results are expressed as mean \pm standard deviation. Different letters indicate significant differences between mean values. $\mathrm{C} \times \mathrm{G}$-interaction between cultivar and growing method.

According to the obtained results, the highest dry matter content was obtained for cv. 'Minimum' both in floating cultivation (10.13\%) and in soil at open field (19.15\%). In floating, cv. 'Minimum' achieved about $1 \%$ higher values of DM compared to the $\mathrm{cv}$. 'Genovese' and 'Dark Opal', while in soil, the differences were slightly higher, DM in cv. 'Minimum' was about 7\% higher compared to cv. 'Genovese' and 'Dark Opal'. Total acid content significantly varied between analyzed basil cultivars only in basil cultivars grown in open field, while in floating, TA values were similar. Significantly higher TA was determined in cv. 'Dark Opal' (0.353 g/100 g fw) compared to the cv. 'Minimum' and 'Genovese' (0.103 and $0.057 \mathrm{~g} / 100 \mathrm{~g} \mathrm{fw})$. According to low TA content, high pH-values of basil cultivars were expected and the differences between cultivars were justified both in floating system and in cultivation at open field. The cultivar 'Minimum' had the highest $\mathrm{pH}$ value (6.31) during the cultivation in floating hydropon, while the cv. 'Genovese', the highest $\mathrm{pH}$ value (6.09) during the cultivation on open field. Regardless the cultivar, slightly higher $\mathrm{pH}$-values were determined in floating (average 6.11) which is in accordance with obtained TA results, since in general, basil cultivars grown in floating had lower TA content.

\subsection{Specialized Metabolites Content and Antioxidant Capacity of Basil Cultivars}

The results of specialized metabolites content are presented in Table 3. According to the statistical analysis, high significant statistical differences $(p \leq 0.0001)$ were determined for all analyzed phytochemicals depending both on the cultivar and cultivation method. Analysis of the significance of the interactions of the individual factors (cultivar and cultivation method) also revealed a significant influence, with the greatest significance determined by their combination $(C \times G)$. 
Table 3. Specialized metabolites content of basil cultivars depending on growing system.

\begin{tabular}{|c|c|c|c|c|}
\hline Cultivar & $\begin{array}{c}\text { Vitamin C } \\
(\mathrm{mg} / 100 \mathrm{~g} \mathrm{fw})\end{array}$ & $\begin{array}{c}\text { TPC (mg } \\
\text { GAE/100 } g \text { fw) }\end{array}$ & $\begin{array}{c}\text { TFC (mg GAE } \\
100 / g \text { fw) }\end{array}$ & $\begin{array}{c}\text { TNFC (mg GAE } \\
100 / \mathrm{g} \mathrm{fw})\end{array}$ \\
\hline \multicolumn{5}{|c|}{ Floating } \\
\hline 'Minimum' & $9.81^{\mathrm{e}} \pm 0.08$ & $350.3^{d} \pm 6.50$ & $181.2^{\mathrm{d}} \pm 1.56$ & $168.6^{d} \pm 20.74$ \\
\hline 'Genovese' & $17.85^{\mathrm{c}} \pm 1.89$ & $259.6^{\mathrm{e}} \pm 4.89$ & $132.7^{\mathrm{e}} \pm 2.26$ & $126.9^{\mathrm{e}} \pm 6.49$ \\
\hline 'Dark Opal' & $57.63^{b} \pm 1.98$ & $511^{\mathrm{c}} \pm 8.98$ & $224.3^{c} \pm 10.43$ & $286.7^{c} \pm 1.46$ \\
\hline \multicolumn{5}{|c|}{ Open field } \\
\hline 'Minimum' & $13.86^{\mathrm{d}} \pm 1.34$ & $1257.8^{\mathrm{a}} \pm 1.77$ & $511.5^{a} \pm 2.99$ & $746.3^{a} \pm 4.18$ \\
\hline 'Genovese' & $13.99^{\mathrm{d}} \pm 1.26$ & $668.7^{b} \pm 11.37$ & $312.9^{b} \pm 22.22$ & $355.7^{\mathrm{b}} \pm 11.25$ \\
\hline 'Dark Opal' & $65.96^{\mathrm{a}} \pm 1.13$ & $660.2^{b} \pm 5.99$ & $322.6^{\mathrm{b}} \pm 9.13$ & $337.6^{\mathrm{b}} \pm 3.67$ \\
\hline ANOVA & $p \leq 0.0001$ & $p \leq 0.0001$ & $p \leq 0.0001$ & $p \leq 0.0001$ \\
\hline LSD & 3.1413 & 14.126 & 23.895 & 18.848 \\
\hline Cultivar (C) & 0.0001 & 0.0001 & 0.0001 & 0.0001 \\
\hline $\begin{array}{l}\text { Growing } \\
\operatorname{method}(\mathrm{G})\end{array}$ & 0.0042 & 0.0001 & 0.0001 & 0.0001 \\
\hline $\mathrm{C} \times \mathrm{G}$ & 0.0002 & 0.0001 & 0.0001 & 0.0001 \\
\hline
\end{tabular}

TPC - total phenol content; TFC-total flavonoid content; TNFC-total non-flavonoid content. Results are expressed as mean \pm standard deviation. Different letters indicate significant differences between mean values. $\mathrm{C}$ $\times$ G-interaction between cultivar and growing method.

Vitamin C content significantly $(p \leq 0.0001)$ varied between basil cultivars in both cultivation methods. The highest vitamin C value was determined for cv. 'Dark Opal' both in floating $(57.63 \mathrm{mg} / 100 \mathrm{~g} \mathrm{fw})$ and in cultivation on open field $(65.96 \mathrm{mg} / 100 \mathrm{~g} \mathrm{fw})$. Additioanlly, between analyzed basil cultivars, the lowest vitamin C content was determined for cv. 'Minimum' (floating-9.81 mg/100 g fw; open field-13.86 mg/100 g fw). Cultivars 'Minimum' and 'Dark Opal' grown on open field obtained significantly higher content of vitamin C compared to floating. Contrary, in cv. 'Genovese', higher vitamin C content was determined while cultivated in floating. Regardless of the cultivars, the higher vitamin $\mathrm{C}$ content was recorded in basil grown in open field ( $31.27 \mathrm{mg} / 100 \mathrm{~g} \mathrm{fw})$ as compared to floating system $(28.43 \mathrm{mg} / 100 \mathrm{~g} \mathrm{fw})$.

Significant differences in total phenolic content (TPC), total flavonoid content (TFC), and total nonflavonoid content (TNFC) were found among basil cultivars and as a function of cultivation method. When basil was grown in a floating system, the highest TPC (511.01 mg GAE /100 g fw), TFC (224.27 (mg GAE / $100 \mathrm{~g} \mathrm{fw}$ ), and TNFC (286.73 (mg GAE $/ 100 \mathrm{~g} \mathrm{fw}$ ) were found for $\mathrm{cv}$. 'Dark Opal', while in the same cropping system, the lowest polyphenol contents were found for $\mathrm{cv}$. 'Genovese'. In contrast, when basil cultivars were grown in the open field, the highest TPC (1257.79 mg GAE / $100 \mathrm{~g} \mathrm{fw})$, TFC (511.45 mg GAE /100 g fw), and TNFC (746.33 mg GAE / $100 \mathrm{~g} \mathrm{fw}$ ) contents were recorded for $\mathrm{cv}$. 'Minimum', while the lowest values for both cv. 'Genovese' and cv. 'Dark Opal'. In general, even twice as high values for TPC, TFC, and also TNFC were obtained when grown in the open field compared to the floating system, regardless of the basil cultivar.

Pigment compounds content of basil cultivars grown in floating and on open field are presented in Table 4. 
Table 4. Pigment compounds content of basil cultivars depending on growing system.

\begin{tabular}{|c|c|c|c|c|c|}
\hline Cultivar & Chl_a (mg/g) & Chl_b (mg/g) & TCh (mg/g) & TCa (mg/g) & TAC (mg/l) \\
\hline \multicolumn{6}{|c|}{ Floating } \\
\hline 'Minimum' & $0.39^{\mathrm{cd}} \pm 0.08$ & $0.18^{c} \pm 0.03$ & $0.59^{\mathrm{cd}} \pm 0.03$ & $0.13^{b} \pm 0.02$ & ND \\
\hline 'Genovese' & $0.65^{\mathrm{a}} \pm 0.11$ & $0.29^{a} \pm 0.08$ & $0.95^{\mathrm{a}} \pm 0.19$ & $0.21^{\mathrm{ab}} \pm 0.03$ & ND \\
\hline 'Dark Opal' & $0.61^{\mathrm{ab}} \pm 0.05$ & $0.28^{a b} \pm 0.02$ & $0.89^{\mathrm{ab}} \pm 0.06$ & $0.35^{\mathrm{a}} \pm 0.24$ & $303.19^{\mathrm{a}} \pm 1.07$ \\
\hline \multicolumn{6}{|c|}{ Open field } \\
\hline 'Minimum' & $0.29^{\mathrm{d}} \pm 0.04$ & $0.24^{\mathrm{abc}} \pm 0.06$ & $0.52^{\mathrm{d}} \pm 0.09$ & $0.09^{b} \pm 0.01$ & ND \\
\hline 'Genovese' & $0.57^{\mathrm{ab}} \pm 0.09$ & $0.21^{b c} \pm 0.04$ & $0.79 \mathrm{ab} \pm 0.13$ & $0.18^{a b} \pm 0.03$ & ND \\
\hline 'Dark Opal' & $0.50^{b c} \pm 0.02$ & $0.22^{b c} \pm 0.008$ & $0.73^{b c} \pm 0.03$ & $0.17^{\mathrm{b}} \pm 0.005$ & $111.52^{a} \pm 10.87$ \\
\hline ANOVA & $p \leq 0.0001$ & $p \leq 0.0336$ & $p \leq 0.0032$ & $p \leq 0.0503$ & $p \leq 0.0001$ \\
\hline LSD & 0.1238 & 0.6909 & 1.7249 & 1.1811 & 8.0449 \\
\hline Cultivar $(\mathrm{C})$ & 0.0001 & 0.2113 & 0.0010 & 0.0684 & 0.0001 \\
\hline $\begin{array}{l}\text { Growing method } \\
(\mathrm{G})\end{array}$ & 0.0130 & 0.2415 & 0.0227 & 0.1019 & 0.0001 \\
\hline$C \times G$ & 0.9377 & 0.0568 & 0.7295 & 0.3459 & 0.0001 \\
\hline
\end{tabular}

Chl_a—chlorophyll a; Chl_b—chlorophyll b; TCh—total chlorophylls; TCa—total carotenoids; —-total anthocyanins; ND—not determined. Results are expressed as mean \pm standard deviation. Different letters indicate significant differences between mean values. $\mathrm{C} \times \mathrm{G}-$ interaction between cultivar and growing method.

Significant statistical differences were found for all pigment compounds analyzed as a function of cultivar and cultivation method, with the most significant being found for chlorophyll a, total chlorophyll, and total anthocyanin content. Taking into account the interaction, i.e., the importance of each factor (cultivar and cultivation method), it can be concluded that the individual influence of cultivar and cultivation method is more significant than when they are combined. Among the analyzed chlorophyll pigments (chlorophyll_a-Chl_a, chlorophyll_b-Chl_b, and total chlorophylls-TCh) of the floating grown basil cultivars, the highest content of all mentioned was found for the cv. 'Genovese' (Chl_a $-0.65 \mathrm{mg} / \mathrm{g}$; Chl_b-0.29 mg/g; TCh $-0.95 \mathrm{mg} / \mathrm{g}$ ), while the lowest values were determined for the cv. 'Minimum' (Chl_a $-0.39 \mathrm{mg} / \mathrm{g}$; Chl_b-0.18 mg/g; TCh-0.59 mg/g). The same tendency of chlorophyll pigment content in relation to variety was found when basil was cultivated in the open field, where again the highest values were found in the cv. 'Genovese' (Chl_a-0.57 mg/g; Chl_b-0.21 mg/g; TCh $-0.79 \mathrm{mg} / \mathrm{g}$ ) and the lowest in the cv. 'Minimum' (Chl_a $-0.29 \mathrm{mg} / \mathrm{g}$; Chl_b-0.24 mg/g; TCh $-0.52 \mathrm{mg} / \mathrm{g}$ ). Total carotenoid content $(\mathrm{TCa})$ regardless of the basil cultivar was in general higher in cultivars grown in floating (on average $0.23 \mathrm{mg} / \mathrm{g}$ ) compared to the cultivation on open field (on average $0.15 \mathrm{mg} / \mathrm{g}$ ). Additionally, significant differences were determined considering the cultivar, with the highest determined TCa for cv. 'Dark Opal' during the growth in floating $(0.35 \mathrm{mg} / \mathrm{g})$ and cv. 'Genovese' during the open field cultivation $(0.18 \mathrm{mg} / \mathrm{g})$. The content of total anthocyanins (TAC) was analyzed only for the cv. 'Dark Opal', where significant differences were found in relation to the cultivation method. In fact, significantly higher values were obtained in the floating cultivation, even about three times.

The antioxidant capacity values of selected basil cultivars as a function of cultivation method are shown in Figure 4. In general, regardless of basil cultivar, about 32\% higher antioxidant capacity was determined for cultivars grown in soil compared to the floating. Statistical differences were not determined for antioxidant capacity between basil cultivars grown in floating (with average value of $1674 \mu \mathrm{mol} \mathrm{TE} / \mathrm{L}$ ), while in cultivation on open field significant differences were determined with the highest antioxidant capacity determined for cv. 'Minimum' (2223 $\mu \mathrm{mol} \mathrm{TE} / \mathrm{L})$ and 'Dark Opal' (2234 $\mu \mathrm{mol} \mathrm{TE} / \mathrm{L})$. 


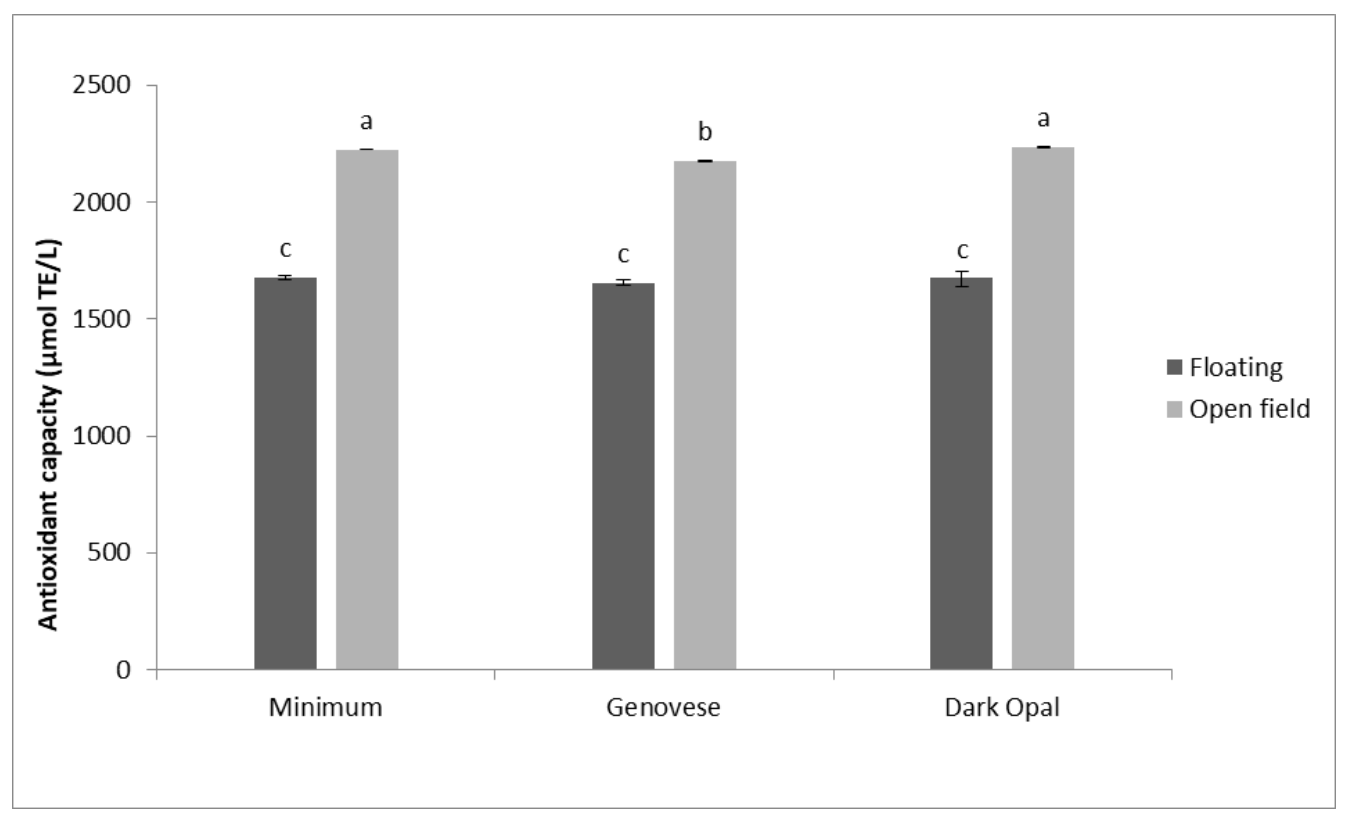

Figure 4. Antioxidant capacity ( $\mu \mathrm{mol}$ TE/L) of three sweet basil cultivars ('Minimum', 'Genovese', 'Dark Opal') grow in floating hydroponic and on open field. Significance of interaction: Cultivar (C) $p \leq 0.0020$; Growing method (G) $p \leq 0.0001$; Interaction $\mathrm{C} \times \mathrm{G} p \leq 0.1308$. Different letters a-c, indicate significant differences between mean values at $p \leq 0.0001$.

\section{Discussion}

\subsection{Morphological Differences of Selected Basic Cultivars}

The species Ocimum basilicum L. is characterized by high morphological and developmental variability [2]. Considerable influence of basil cultivars is confirmed by this research as well (Table 1 and Figure 1), as the higher values of the most morphological properties (plant mass and height, dimensions of leaves, and total yield) in both growing methods were achieved by the cultivar 'Genovese'. Contrary, 'Minimum' had lower values of the specified properties, except the number of leaves, compared to the 'Dark Opal' and especially the 'Genovese'. The mentioned trend was expected since the genetic characteristics define morphological plant properties. Namely, 'Minimum' is dwarf cultivar with very small (less than $1 \mathrm{~cm}$ long) leaves, while 'Genovese' and 'Dark Opal' belong to cultivars with leaves larger than $5 \mathrm{~cm}$ [4]. According to Nurzyńska-Wierdak and Borowski [2], the height and width of basil plants depend mainly upon the environmental conditions, whereas the shape, surface, and edge of leaf are genetically conditioned and constitute the identification features of cultivars.

All three cultivars studied obtained higher yields in the floating system than in the soil, these values being $97 \%$ higher for 'Minimum', 32\% higher for 'Genovese', and 16\% higher for 'Dark Opal'. This confirms the great influence of the growing method, despite the conditionality of the genetic characteristics of the cultivars. In general, plants grown in the floating system had larger leaves by $46 \%$ (length) and 39\% (width), and the plants were $14 \%$ taller than those grown in the open field, resulting in a higher total yield (by $39 \%)$. The average basil yield obtained in this study in the floating system $\left(2.62 \mathrm{~kg} / \mathrm{m}^{2}\right)$ is similar to the values cited by Miceli et al. [10]. Other citations [13,14] have also confirmed that herbs can grow larger in a hydroponic solution compared to soil, which is reflected in a higher yield. The reason for this is better control of the abiotic air, factors due to growing in protected greenhouses, then the availability of sufficient nutrients and water, and finally the sowing density compared to planting in the soil, as in earlier, research on the arugula and stinging nettle was confirmed by the authors Toth et al. [12] and Radman et al. [27]. Regardless of their genetic differences, all three cultivars achieved their genetic potential in the floating system since the higher total yield was recorded compared to growing in 
the soil in the open field. The advantage of floating cultivation is that the production cycle from sowing to first harvest is twice as short (59 days) compared to conventional soil cultivation (116 days). In addition, there is less technological intervention on the plants, while cultivation in the field requires the raising of transplants in a protected greenhouse, which must be pricked before planting in the field. It is easier to control abiotic factors, which reduces the risks in production, the system is sustainable and environmentally friendly, and cultivation is possible in locations without soil or with poor soil properties.

\subsection{Nutritional Composition, Specialized Metabolites Content, and Antioxidant Capacity of Basil Cultivars}

Basil is known as an aromatic plant species with great genetic diversity, with about 150 reported and described species that differ greatly in various morphological characteristics, but also in chemical composition and content of various specialized metabolites [28]. According to the obtained results of physico-chemical parameters of analyzed basil cultivars (Table 2), a strong influence of basil genetic characteristics and cultivation method on the content of $\mathrm{DM}, \mathrm{TA}$, and $\mathrm{pH}$ value can be demonstrated. In both cultivation methods, $\mathrm{cv}$. 'Minimum' can be highlighted for the highest DM content, while cv. 'Genovese' and 'Dark Opal' had statistically similar DM content. Significant differences in DM content were also determined considering the cultivation method. All analyzed basil cultivars grown in soil at the open field had higher DM values, about 5\% higher, compared to the floating cultivation, which was expected since floating cultivation requires a constant supply of nutrient solution to the plants, resulting in lower DM accumulation and higher moisture content in plant material $[11,29,30]$. Basil cultivation in soil on open field necessarily requires irrigation, as basil generally has a high-water requirement, but the irrigation regimes for growing on open field do not include a constant water supply as in floating cultivation. These obtained results can be supported by the results of other authors; the authors Seidler-Łożykowska et al. [31] reported values of DM for fresh basil leaves grown in the open field, with an average content of $16.13 \%$, while Saha et al. [32] found DM values on average of $9.6 \%$ for basil grown in hydroponics. Regardless of basil cultivar and cultivation method, low total organic acid content was determined in all samples, indicating that basil as an aromatic plant is not a significant source of acids with the exception of phenolic and lipoic acids [11,30]. In floating cultivation, significant differences in TA content between different basil cultivars were not determined. In soil cultivation in open field, significant differences in TA content were established but also in very low content. In accordance with low TA content, $\mathrm{pH}$ values of basil cultivars grown both in floating and in soil in open field were relatively high which was expected.

One of the major aims and challenges among scientists is cultivation of high nutritional quality raw materials with significant content of bioactive compounds with important roles for human health. However, in addition, today's agricultural practices, in addition to producing high-quality raw materials, require the use of sustainable systems with the least possible impact on the environment, reduced use of pesticides, chemical or mineral fertilizers, and intensive use of the soil. It follows from all this that, by introducing varieties with a significant nutritional composition, i.e., higher levels of specific phytochemicals, combined with sustainable cultivation practices, we can make an important contribution to meeting market requirements, but also to preserving and protecting the environment. Production of high-quality aromatic plants can be affected by among factors, especially by genetic diversity of cultivars and cultivation method i.e., abiotic factors. One of the best-known ingredients of aromatic medicinal plants is vitamin $C$, which has significant antioxidant activity, making it a valuable dietary ingredient. According to the results obtained in this research, the lowest vitamin C content was determined for cv. 'Minimum' both in floating and in open field cultivation, while cv. 'Dark Opal' recorded highest vitamin C content in both applied growing systems. For example, during the floating cultivation, cv. 'Dark Opal' recorded even 6 times higher vitamin C content compared to the cv. 'Minimum' and about 3 times compared to the cv. 'Genovese', while during the cultivation in open field, these differences were also significant whereby cv. 'Dark Opal' had even 5 times higher vitamin 
content both compared to the cv. 'Minimum' and 'Genovese'. Additionally, different studies suggest a significant variability of vitamin $C$ content between basil cultivars, for example, Saadatian et al. [33], Majkowska-Gadomska et al. [34], and Majkowska-Gadomska et al. [35] also reported significantly higher vitamin $C$ values in purple basil varieties compared to the sweet basil ones. In general, results of vitamin $C$ content from this study are in agreement with data obtained in other research $[11,35,36]$. Looking at the influence of the cultivation system on vitamin C content, it is noticeable, regardless of the cultivar, that vitamin $C$ content is lower in floating cultivation than in open field cultivation, which can be explained by the role of vitamin C (ascorbic acid, AsA) in plant defense against ROS (reactive oxygen species), which accumulates in cells when the plant is exposed to stress (mainly due to abiotic factors such as drought stress, high temperatures, etc.). Indeed, when plants are grown in the open, it is impossible to fully control environmental conditions, i.e., plants are exposed to stresses in which the plant develops stronger defense mechanisms, such as the accumulation of certain antioxidants, such as AsA [37]. In contrast, when plants are grown in protected areas, especially hydroponic cultivation, they find optimal conditions for growth and development, during which they are less often exposed to abiotic or biotic stresses and therefore do not develop defense mechanisms or tend to accumulate more secondary metabolites. Based on the above, the higher vitamin $C$ content in basil cultivars grown outdoors can be explained by the mechanisms and metabolic pathways of compound synthesis in response to stress. This statement can also be supported by the research results of a group of authors, Sgherri et al. [11], who also found significant differences in phytochemicals in relation to cultivation method, also determined higher levels of vitamin $C$ in the basil cultivars grown on open field. Besides mentioned, the significant antioxidant role also exhibited plant compounds called specialized metabolites, respectively polyphenols, of which their main role is direct impact on the plant protection mechanism secondary metabolites. Biotic, abiotic, and anthropogenic factors significantly influence their synthesis and accumulation in plant cells [38]. In this study, genetic variability had a significant effect on the analyzed polyphenolic compounds, TPC, TFC, and TNFC, but even more pronounced was the effect of the cultivation method. Comparing the TPC content in different basil cultivars grown in floating, the highest content is observed in the cv. 'Dark Opal', which is as much as $46 \%$ higher than in the cv. 'Minimum' or even $97 \%$ compared to cv. 'Genovese'. Cultivar 'Genovese' is one of the most popular cultivars among the sweet basil varieties, both in production and consumption, but if we consider the TPC content, it is important to emphasize the need for a greater introduction of other cultivars (e.g., 'Minimum' and 'Dark Opal'), especially from a nutritional and health point of view, since polyphenols are one of the most powerful antioxidants. When grown in the open field, the TPC content showed a slightly different trend with respect to variety, with the highest content determined in the cv. 'Minimum', even $88 \%$ higher than in the cv. 'Genovese' and 91\% higher than in cv. 'Dark Opal'. The same significant influence of genetic characteristics on the content of polyphenolic compounds has been found by other authors. For example, Kwee and Niemeyer [28] found significant statistical differences in the content of total phenolic compounds among 15 analyzed basil varieties with the highest determined TPC for cv. 'Spice', which is characterized by shrub growth and small leaves similar to the cv. 'Minimum' from this research. Additionally, Saadatian et al. [33] proved significantly higher values of total phenols in purple compared to the sweet (green) basil varieties which is partly consistent with the results from this research in which was determined higher TPC, TFC, and TNFC for cv. 'Dark Opal' (purple basil) compared to the cv. 'Genovese' (green basil). If we compare the influence of the cultivation method on the content of polyphenolic compounds, we can see an even more significant influence. In general, regardless of cultivar, TPC, TFC, and TNFC contents were higher in basil cultivars grown outdoors than in hydroponics (greenhouse). The highest increase in TPC as a function of cultivation method was observed in cv. 'Minimum', which even showed an approximately 4-fold higher TPC content when grown in open field compared to floating cultivation. Furthermore, cv. 'Genovese' also showed a higher TPC content when grown 
outdoors, by a factor of 3 compared to floating cultivation, while the same trend was also observed for the cv. 'Dark Opal', which showed a 30\% higher TPC content when grown in open field compared to floating cultivation. In fact, the polyphenolic compounds are the most important compounds of plant secondary metabolism, primarily responsible as a plant defense mechanism and the most important role in plant organism responses to stress. Indeed, the phenylpropanoid biosynthetic pathway leading to the accumulation of various phenolic compounds is activated in plants under stressful environmental conditions. Thus, ultimately, the accumulation of polyphenolic compounds may be regulated by various environmental factors such as water availability, wounding, insect herbivory, nutrient deficiency and availability, light exposure, developmental stage of the plant, etc. [38-40]. According to the results from this research, placed ascertainment can be confirmed since significantly higher TPC, TFC, and TNFC were obtained in basil cultivars grown in open field compared to the hydroponics in greenhouse (Table 3).

Colored pigments compounds play different roles in plant organisms. Chlorophylls are the main pigments responsible for the photosynthesis, carotenoids exhibit an important photoprotective role in higher plants [41], while anthocyanins protect plant organs against many abiotic stressors, mainly reduce photo-oxidative injury in leaves [7,42]. Besides, mentioned pigments also have an important role in human organisms since they exhibit anticancer, antimicrobial, antioxidant effects etc. [43]. Comparing the TCh content among different basil cultivars can confirm that genetic characteristics play an important role also in terms of pigment compounds since in green leafy basil cv. 'Genovese' regardless of cultivation method, the highest TCh content was determined. More precisely, cv. 'Genovese' grown in floating had even $61 \%$ higher TCh content compared to the cv. 'Minimum' and $52 \%$ higher when grown in soil, and compared to cv. 'Dark Opal', about 7\% in floating and $8 \%$ in soil. TCh content was in general higher in all basil cultivars grown in floating compared to the cultivars grown in open field. For example, in cv. 'Genovese' grown in floating, 20\% higher TCh content was determined compared to values obtained from cultivation on open field. The highest TCa content $(0.35 \mathrm{mg} / \mathrm{g})$ was determined for $\mathrm{cv}$. 'Dark Opal' grown in floating, while all obtained TCa values differ between cultivar and growing method. In general, higher TCa content was determined in basil cultivars grown in floating, on average regardless of cultivar, even $57 \%$ higher values compared to the cultivation on open field. TAC content determined in purple basil cultivar 'Dark Opal' significantly differed according to the growing method. Even about three times higher TAC content was obtained in cv. 'Dark Opal' grown in floating compared to the cultivation on open field. Indeed, the content and accumulation of plant pigment compounds is directly related to the process of photosynthesis, while the light (UV radiation) is one of the key factors in their synthesis in the leaf. The main role of pigment compounds is to protect the plant from too much irradiation (photoprotective role), and when the plant is exposed to too much sunlight, it activates defense mechanisms, begins to reduce stomatal conduction, which leads to reduced activity of RUBISCO enzymes, which negatively affects photosystem I and II, photosynthetic electron transport, ultimately leading to reduced chlorophyll biosynthesis [44]. Since the role of carotenoids is the same as that of chlorophyll, where they also protect chlorophyll, the reduction in chlorophyll content also leads to the reduction of carotenoids levels. Therefore, the results obtained in this study, i.e., the increased content of chlorophyll, carotenoids, and anthocyanins in all basil cultivars grown in floating, can be explained by the fact that plants grown in greenhouses were better protected from the direct effects of irradiation compared to plants grown in open field. Those results can be also supported by the other literature data $[33,36,45-48]$.

Antioxidant activity of plant material is in direct correlation with the content of biologically active compounds often called SM, mainly vitamins, polyphenols, pigments etc. [49]. Their antioxidant role is associated with the possibility of neutralization of oxidation processes by inhibition of free radicals and detoxification of ROS [50,51]. From results obtained in this research, it can be concluded that all analyzed basil cultivars have high antioxidant capacity which is in agreement with other literature data $[11,33,52]$. 
Additionally, it is evident that basil cultivars grown in open field had significantly higher antioxidant capacities compared to the cultivars grown in floating which was expected considering that samples grown in open field also have higher amounts of TPC, TFC, TNFC, and vitamin C (Tables 3 and 4), recognized as one of the compounds with the strongest antioxidant action.

\section{Conclusions}

Based on the conducted research, it can be concluded that the genetic characteristics, i.e., basil cultivars, have a significant influence, not only on morphological characteristics, but also on the content of specific phytochemicals, bioactive compounds. Among the analyzed selected basil cultivars, the cv. 'Dark Opal' stands out with the highest content of vitamin C (on average $61.79 \mathrm{mg} / 100 \mathrm{~g} \mathrm{fw}$ ), high content of total phenols (on average $585.62 \mathrm{mg}$ GAE/ $100 \mathrm{~g} \mathrm{fw}$ ), flavonoids and non-flavonoids, and pigment compounds (total chlorophyll, carotenoids, and anthocyanins). Due to the high content of bioactive compounds, the cv. 'Dark Opal' can also be distinguished by the highest determined value of antioxidant capacity (on average $1954 \mu \mathrm{mol} \mathrm{TE} / \mathrm{L}$ ). In addition to the genetic characteristics, the cultivation method had an even more pronounced influence on the content of specialized metabolites. In cultivation on open field, significantly higher values of vitamin C were found, about 10\%, even double the value of total phenols and $32 \%$ higher antioxidant capacity, regardless of the cultivar. On the other hand, significantly higher levels of pigment compounds were found in floating cultivation, with about $20 \%$ higher total chlorophylls, $50 \%$ higher total carotenoids, and three times higher total anthocyanins compared to cultivation on open field. Cultivation in floating resulted in $37 \%$ higher yield compared to the open field cultivation, earlier harvest, and also shorter production cycle of all three studied cultivars. So finally, it can be stated that selection of cultivar but also cultivation method are crucial technological factors. Future research should focus on more detailed analyses of the phytochemicals of basil, i.e., the analysis of individual compounds with developed HPLC techniques is necessary to gain an even more detailed insight into the influence of cultivation methods (multiple harvesting), but also genetic traits on the overall quality of the plant material.

Author Contributions: Conceptualization, J.Š.Ž. and S.R.; Methodology, S.F.U. and J.Š.Ž.; Investigation, S.R. and M.P.; Analysis, S.F.U. and M.P., Writing—original draft preparation, N.O. and S.F.U.; Writing-review and editing, I.Ž., S.V and B.B.; Visualization, B.B., N.O. and I.Ž.; Supervision, J.Š.Ž.; All authors have read and agreed to the published version of the manuscript.

Funding: This research received no specific grant from any funding agency, commercial or not-forprofit sectors.

Conflicts of Interest: The authors declare there are no conflicts of interest.

\section{References}

1. Kalamartzis, I.; Dordas, C.; Georgiou, P.; Menexes, G. The Use of Appropriate Cultivar of Basil (Ocimum basilicum) Can Increase Water Use Efficiency under Water Stress. Agronomy 2020, 10, 70. [CrossRef]

2. Nurzyńska-Wierdak, R.; Borowski, B. Dynamics of sweet basil (Ocimum basilicum L.) growth affected by cultivar and foliar feeding with nitrogen. Acta Sci. Pol. Hort. Cult. 2011, 10, 307-317.

3. Ćavar Zeljković, S.; Komźaková, K.; Šišková, J.; Karalija, E.; Smékalová, K.; Tarkowski, P. Phytochemical variability of selected basil genotypes. Ind. Crops Prod. 2020, 157, 112910. [CrossRef]

4. Makri, O.; Kintzios, S. Ocimum sp. (basil): Botany, cultivation, pharmaceutical properties, and biotechnology. J. Herbs Spices Med. Plants 2008, 13, 123-150. [CrossRef]

5. Zervoudakis, G.; Salahas, G.; Rodi, M. Nitrogen nutrition effect on aeroponic basil (Ocimum basilicum L.) catalase and lipid peroxidation. Not. Bot. Horti. Agrobot. Cluj Napoca 2015, 43, 561-567. [CrossRef]

6. Falowo, A.B.; Mukumbo, F.E.; Idamokoro, E.M.; Afolayan, A.J.; Muchenje, V. Phytochemical Constituents and Antioxidant Activity of Sweet Basil (Ocimum basilicum L.) Essential Oil on Ground Beef from Boran and Nguni Cattle. Int. J. Food Sci. 2019, 2019. [CrossRef]

7. Kiferle, C.; Lucchesini, M.; Mensuali-Sodi, A.; Maggini, R.; Raffaelli, A.; Pardossi, A. Rosmarinic acid content in basil plants grown in vitro and in hydroponics. Cent. Eur. J. Biol. 2011, 6, 946-957. [CrossRef] 
8. Kwon, D.Y.; Li, X.; Kim, J.K.; Park, S.U. Molecular cloning and characterization of rosmarinic acid biosynthetic genes and rosmarinic acid accumulation in Ocimum basilicum L. Saudi J. Biol. Sci. 2019, 26, 469-472. [CrossRef]

9. Fallah, M.S.; Bayati, M.; Behmard, E.; Davarpanah, S.J. Molecular Docking Investigation of Antiviral Herbal Compounds as Potential Inhibitors of SARS-CoV-2 Spike Receptor. Biointerface Res. Appl. Chem. 2021, 11, 12916-12924.

10. Miceli, A.; Moncada, A.; Vetrano, F.; D'Anna, F. First results on yield and quality response of basil (Ocimum basilicum L.) grown in a floating system. Int. Symp. Manag. Greenh. Crops Saline Environ. 2003, 609, 377-381. [CrossRef]

11. Sgherri, C.; Cecconami, S.; Pinzino, C.; Navari-Izzo, F.; Izzo, R. Levels of antioxidants and nutraceuticals in basil grown in hydroponics and soil. Food Chem. 2010, 123, 416-422. [CrossRef]

12. Toth, N.; Fabek, S.; Benko, B.; Žutić, I.; Stubljar, S.; Zeher, S. The effect of abiotic factors, sowing density and multiple harvest to arugula yield in floating hydroponic. Glas. Zaštite Bilja 2012, 35, 24-34.

13. Chandra, S.; Khan, S.; Avula, B.; Lata, H.; Yang, M.H.; ElSohly, M.A.; Khan, I.A. Assessment of total phenolic and flavonoid content, antioxidant properties, and yield of aeroponically and conventionally grown leafy vegetables and fruit crops: A comparative study. Evid Based Complement Alternat Med. 2014, 253875. [CrossRef] [PubMed]

14. Akoumianaki-Ioannidou, A.; Rasouli, M.; Podaropoulou, L.; Karapanos, I.; Bilalis, D. Effects of Cultivation System and Fertilization on Seedling Production of Ocimum basilicum L. and Mentha spicata L. Not. Bot. Hort. Agrobot. Cluj. 2015, 43, 131-137. [CrossRef]

15. Kolega, S.; Miras-Moreno, M.; Buffagni, V.; Lucini, L.; Valentinuzzi, F.; Maver, M.; Mimmo, T.; Trevisan, M.; Pii, Y.; Cesco, S. Nutraceutical Profiles of Two Hydroponically Grown Sweet Basil Cultivars as Affected by the Composition of the Nutrient Solution and the Inoculation with Azospirillum brasilense. Front. Plant Sci. 2020, 11. [CrossRef] [PubMed]

16. Osvald, J.; Kogoj-Osvald, M. Hidroponsko gojenje vrtnin; Univerza v Ljubljani, Biotehniška fakulteta, Oddelek za agronomijo: Ljubljana, Slovenija, 2005.

17. Tesi, R. Colture Fuori Suolo in Orticoltura e Floricoltura; Edagricole: Bologna, Italy, 2002.

18. Máthé, A. Medicinal and Aromatic Plants of the World: Scientific, Production, Commercial and Utilization Aspects; Springer: Dortrecht, Germany, 2015.

19. CMHS. Croatian Meteorological and Hydrological Service. Available online: https://meteo.hr/index_en.php (accessed on 4 November 2019).

20. AOAC. Official Methods of Analysis, 16th ed.; Association of Official Analytical Chemists: Washington, DC, USA, 1955.

21. AOAC. Official Methods of Analysis, 17th ed.; Association of Official Analytical Chemists: Washington, DC, USA, 2002.

22. Ough, C.S.; Amerine, M.A. Methods for Analysis of Musts and Wines; John Wiley \& Sons: New York, NJ, USA, 1988.

23. Holm, G. Chlorophyll mutations in barley. Acta Agric Scand. 1954, 4, 457-471. [CrossRef]

24. Wettstein, D. Chlorophyll letale und der submikroskopische Formwechsel der Plastiden. Exp. Cell Res. 1957, 12, 427-434. [CrossRef]

25. Miller, N.J.; Diplock, A.T.; Rice-Evans, C.; Davies, M.J.; Gopinathan, V.; Milner, A. A novel method for measuring antioxidant capacity and its application to monitoring the antioxidant status in premature neonates. Clin. Sci. 1993, 84, 407-412. [CrossRef] [PubMed]

26. SAS Institute. SAS®/STAT 9.3; SAS Institute Inc: Cary, NC, USA, 2011.

27. Radman, S.; Fabek, S.; Žutić, I.; Benko, B.; Toth, N. Stinging nettle cultivation in floating hydropon. Contemp. Agric. 2014, 63, 215-223.

28. Kwee, E.M.; Niemeyer, E.D. Variations in phenolic composition and antioxidant properties among 15 basil (Ocimum basilicum L.) cultivars. Food Chem. 2011, 128, 1044-1050. [CrossRef]

29. Fontana, E.; Nicola, S. Traditional and soilless culture systems to produce corn salad (Valerianella olitoria L.) and rocket (Eruca sativa Mill.) with low nitrate content. J. Food Agric. Environ. 2009, 7, 405-410.

30. Lu, Y.; Gao, B.; Chen, P.; Charles, D.; Yu, L.L. Characterization of organic and conventional sweet basil leaves using chromatographic and flow-injection mass spectrometric (FIMS) fingerprints combined with principal component analysis. Food Chem. 2014, 154, 262-268. [CrossRef]

31. Seidler-Łożykowska, K.; Galambosi, B.; Król, D. Herb yield, essential oil content and its composition in two cultivars of sweet basil (Ocimum basilicum L.) grown in two different locations. Herba Pol. 2008, 54, 35-42.

32. Saha, S.; Monroe, M.; Day, M.R. Growth, yield, plant quality and nutrition of basil (Ocimum basilicum L.) under soilless agricultural systems. Ann. Agric. Sci. 2016, 61, 181-186. [CrossRef]

33. Saadatian, M.; Peyvast, G.; Olfati, J.A.; Ramezani-Kharazi, P. Different species of basil need different ammonium to nitrate ratio in hydroponics' system. Acta Agric. Slov. 2014, 103, 223-232. [CrossRef]

34. Majkowska-Gadomska, J.; Kulczycka, A.; Dobrowolski, A.; Mikulewicz, E. Yield and nutritional value of basil grown in a greenhouse. Acta Agrophys. 2017, 24, 455-464.

35. Majkowska-Gadomska, J.; Dziedzic, A.; Dobrowolski, A.; Mikulewicz, E. The effect of sowing time on the yield and nutritional value of Basil (Ocimum basilicum L.) herbage. Acta Agrophys. 2015, 22, 165-172.

36. Dumbravă, D.G.; Moldovan, C.; Raba, D.N.; Popa, M.V. Vitamin C, chlorophylls, carotenoids and xanthophylls content in some basil (Ocimum basilicum L. ) and rosemary (Rosmarinus officinalis L.) leaves extracts. J. Agroaliment. Process. Technol. 2012, 18, 253-258.

37. Huang, H.; Ullah, F.; Zhou, D.X.; Yi, M.; Zhao, Y. Mechanisms of ROS Regulation of Plant Development and Stress Responses. Front. Plant Sci. 2019, 10, 1-10. [CrossRef] 
38. Wink, M. Functions and Biotechnology of Plant Secondary Metabolites, 2nd ed.; Wiley-Blackwell: Oxford, UK, 2010.

39. Mewis, I.; Khan, M.A.M.; Glawischnig, E.; Schreiner, M.; Ulrichs, C. Water Stress and Aphid Feeding Differentially Influence Metabolite Composition in Arabidopsis thaliana (L.). PLoS ONE 2012, 7. [CrossRef]

40. Isah, T. Stress and defense responses in plant secondary metabolites production. Biol. Res. 2019, 52, 1-25. [CrossRef]

41. Brotosudarmo, T.H.P.; Limantara, L.; Chandra, R.D.; Heriyanto. Chloroplast Pigments: Structure, Function, Assembly and Characterization, Plant Growth and Regulation-Alterations to Sustain Unfavorable Conditions; Ratnadewi, D., Hamim, H., Eds.; IntechOpen: London, UK, 2018. Available online: https:/ / www.intechopen.com/books/plant-growth-and-regulation-alterations-to-sustainunfavorable-conditions/chloroplast-pigments-structure-function-assembly-and-characterization (accessed on 8 March 2021). [CrossRef]

42. Landi, M.; Tattini, M.; Gould, K.S. Multiple functional roles of anthocyanins in plant-environment interactions. Environ. Exp. Bot. 2015, 119, 4-17. [CrossRef]

43. Chen, C. Pigments in Fruits and Vegetables: Genomics and Dietetics; Springer: New York, NY, USA, 2015.

44. Sharma, A.; Kumar, V.; Shahzad, B.; Ramakrishnan, M.; Sidhu, G.P.S.; Bali, A.S.; Handa, N.; Kapoor, D.; Yadav, P.; Khanna, K.; et al. Photosynthetic Response of Plants Under Different Abiotic Stresses: A Review. J. Plant. Growth Regul. 2020, 39, 509-531. [CrossRef]

45. Kalisz, A.; Jezdinský, A.; Pokluda, R.; Sękara, A.; Grabowska, A.; Gil, J. Impacts of Chilling on Photosynthesis and Chlorophyll Pigment Content in Juvenile Basil Cultivars. Hortic. Environ. Biotechnol. 2016, 57, 330-339. [CrossRef]

46. Santamaria, P.; Elia, A.; Serio, F. Effect of solution nitrogen concentration on yield, leaf element content, and water and nitrogen use efficiency of three hydroponically-grown rocket salad genotypes. J. Plant. Nutr. 2002, 25, 245-258. [CrossRef]

47. Vernieri, P.; Borghesi, E.; Tognoni, F.; Ferrante, A.; Serra, G.; Piaggesi, A. Use of Biostimulants for Reducing Nutrient Solution Concentration in Floating System. In Proceedings of the III International Symposium on Models for Plant Growth, Environmental Control and Farm Management in Protected Cultivation, Wageningen, The Netherlands, 29 October 2006; Volume 718, pp. 477-484.

48. Žnidarčić, D.; Ban, D.; Šircelj, H. Carotenoid and chlorophyll composition of commonly consumed leafy vegetables in Mediterranean countries. Food Chem. 2011, 129, 1164-1168. [CrossRef]

49. Durazzo, A. Study Approach of Antioxidant Properties in Foods: Update and Considerations. Foods 2017, 6, 17. [CrossRef]

50. Dai, J.; Mumper, R.J. Plant Phenolics: Extraction, Analysis and Their Antioxidant and Anticancer Properties. Molecules 2010, 15, 7313-7352. [CrossRef]

51. Šic Žlabur, J.; Voća, S.; Dobričević, N.; Pliestić, S.; Galić, A.; Boričević, A.; Borić, N. Ultrasound-assisted extraction of bioactive compounds from lemon balm and peppermint leaves. Int. Agrophys. 2016, 30, 95-104. [CrossRef]

52. Veronezi, C.M.; Costa, T.; Jorge, N. Basil (Ocimum basilicum L.) as a natural antioxidant. J. Food Process. Preserv. 2014, 38, $255-261$. [CrossRef] 